\title{
EAl Endorsed Transactions

\section{Operational reliability as a resource for increasing the efficiency of electromechanical systems of rope shovels}

\author{
I.A. Lobur ${ }^{1}$, A.G. Zaharova ${ }^{1, *}$, N.M. Shauleva ${ }^{1}$ and V.A. Borovtsov ${ }^{1}$ \\ ${ }^{1}$ T.F. Gorbachev Kuzbass State Technical University, 28 street Vesennyaya, Kemerovo, 650000, Russian Federation
}

\section{Abstract}

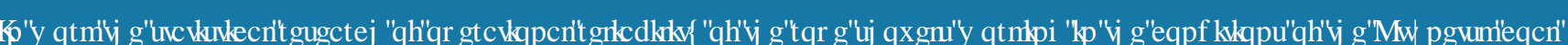

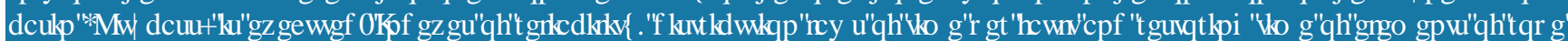

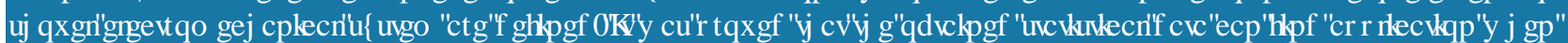

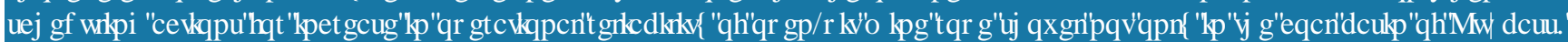
DORIQIRMNUUH IRQVZ LMRSHQSIGP IQQ [RILFRD]

Keywords: reliability, rope shovel, time per fault, restoring time.

Received on 18 June 2018, accepted on 03 December 2018, published on 31 January 2019

Copyright (C) 2019 I.A. Lobur et al., licensed to EAI. This is an open access article distributed under the terms of the Creative Commons Attribution licence (http://creativecommons.org/licenses/by/3.0/), which permits unlimited use, distribution and reproduction in any medium so long as the original work is properly cited.

doi: 10.4108/eai.13-7-2018.156437

"Corresponding author. Email: zaharova8@ gmail.com

\section{Introduction}

The Kuznetsk coal basin (Kuzbass) is one of the most large-scale coal de-posits of the world. It is located in Western Siberia, in the territory of the Kemerovo region.

In the last time a number of measures for strengthening of the material re-sources of electromechanical service on open-pit mines is taken. These measures positively affect on lost time reduction of electric mine equipment at the emergency and scheduled repairs. In this regard, it is impossible to use the data on reliability obtained earlier without the necessary adjustment as essential mistakes when calculating are possible.

Need to provide the required accuracy of the end results is other reason and therefore indicators of reliability as a basis for calculations have to be received with a high fiducial probability. Thus, carrying out researches of an electromechanical inventory reliability of open-pit mines is very important task.

By data [1] on average on one planned repair stop is necessary 12 failures of the rope shovel, and fall on one hour of its work in the mode of dredging loading of mining rock weight $-1,5-2,0 \mathrm{~h}$ idle time in the system of repair. In [2] it is shown that the rope shovel calendar time capacity factor on Kuzbass open-pit mines makes $0,57-0,68$, and failures of electric equipment make up to $40 \%$ of all number of malfunctions [3 - 6]. Such rather low indexes are explained, mainly, by a large number and duration of idle times which main part is connected to need of realization of various emergency repairs. In this regard increase in reliability of electric equipment is an important reserve of increase in productivity of a mining inventory in open-pit mines.

\section{Technique of collecting and pro- cessing of statistical information on reliability of various systems of open-pit mines}

According to [7, 17] information on reliability of products has to correspond to requirements of reliability, completeness and uniformity. The reliability of the obtained information is provided with the operation control system of electric equipment, competence and responsibility of the persons observing. The regularity and timeliness of the received information is provided with continuous filling out of registration documents. The 
completeness of information is provided with the total and precise reflection of all information on term of use and an inventory operability.

The institute of mining of A.A. Skochinsky developed a complex technique of collecting and processing of statistical data on operational reliability of mine electric equipment [18] which can be assumed as a basis in relation to electric equipment of open-pit mines. According to this technique for ensuring reliability of the indicators of reliability obtained as a result of processing of statistical data it is necessary to receive in advance established sample size (the number of breakages and time of repair) caused by necessary time of observation of particular number of an inventory. For this purpose it is necessary to know the guaranteed sample size 16 which would satisfy a fiducial probability $\alpha$ and the limiting relative error $\delta$. The value of a fiducial probability should be chosen not below $\alpha \geq 0,8$, and value of the limiting relative error $\delta \leq 0,25$. The most expedient $\alpha$ values $=0,9$ $\div 0,95, \delta=0,1 \div 0,05$.

\section{Operational reliability of electromechanical system of open-pit mine rope shovels}

Reliability of electromechanical system of open-pit mine rope shovels is defined by reliability of its separate parts: mechanical, electric and control systems. Various factors of mining also have significant effect on reliability and safety of functioning of rope shovels and their elements.

When studying this problem statistical data from 6 open-pit mines which belong to JSC Kuzbassrezrezugol Coal Company were obtained and investigated, namely on open-pit mines Kedrovsky, Krasnobrodsky and Mokhovsky for 2014-2015, and on open-pit mines Bachatsky, Kaltansky, Taldinsky for 2012-2013. The obtained data were consolidated in statistical ranks and processed on the personal computer by the known methods of mathematical statistics [7 - 12] with use of the software of Microsoft Office Excel 2013 and Statistica 13 Trial.

The distribution law parameters of rope shovel electromechanical system are presented in tab. 1.

Table 1. The distribution law parameters of a time per fault of rope shovel electromechanical system

\begin{tabular}{|c|c|c|c|c|c|}
\hline $\begin{array}{l}\text { Ele- } \\
\text { ments } \\
\text { sys- } \\
\text { tems }\end{array}$ & $\begin{array}{l}\text { Time of } \\
\text { obser- } \\
\text { vation } t, h\end{array}$ & $\begin{array}{l}\text { Quantity } \\
\text { of random } \\
\text { values in a } \\
\text { row }\end{array}$ & $\begin{array}{l}\text { Failure } \\
\text { rate } \\
\lambda \cdot 10-3, \\
1 / \mathrm{h}\end{array}$ & $\begin{array}{l}\text { Average } \\
\text { time per } \\
\text { fault } t_{0}, h\end{array}$ & $\begin{array}{l}\text { Distri- } \\
\text { bution } \\
\text { law }\end{array}$ \\
\hline \multicolumn{6}{|c|}{ Kedrovsky open-pit mine } \\
\hline $\begin{array}{l}\text { Mecha- } \\
\text { nical part }\end{array}$ & & 627 & 30,3 & 32,9 & $\begin{array}{l}\text { Expo- } \\
\text { nential }\end{array}$ \\
\hline $\begin{array}{l}\text { Electric } \\
\text { part }\end{array}$ & 17520 & 640 & 78,1 & 12,8 & $\begin{array}{l}\text { Expo- } \\
\text { nential }\end{array}$ \\
\hline
\end{tabular}

\begin{tabular}{|c|c|c|c|c|c|}
\hline \multirow{2}{*}{$\begin{array}{l}\text { Control } \\
\text { system }\end{array}$} & 17520 & 77 & 11,8 & 84,6 & $\begin{array}{l}\text { Expo- } \\
\text { nential }\end{array}$ \\
\hline & \multicolumn{4}{|c|}{ Krasnobrodsky open-pit mine } & \\
\hline $\begin{array}{l}\text { Mecha- } \\
\text { nical } \\
\text { part }\end{array}$ & 17520 & 810 & 28,1 & 48,3 & $\begin{array}{l}\text { Expon } \\
\text { ential }\end{array}$ \\
\hline $\begin{array}{l}\text { Electric } \\
\text { part }\end{array}$ & 17520 & 793 & 91,2 & 23,3 & $\begin{array}{l}\text { Expo- } \\
\text { nential }\end{array}$ \\
\hline \multirow[t]{2}{*}{$\begin{array}{l}\text { Control } \\
\text { system }\end{array}$} & 17520 & 91 & 19,3 & 93,2 & $\begin{array}{l}\text { Expo- } \\
\text { nential }\end{array}$ \\
\hline & \multicolumn{4}{|c|}{ Mokhovsky open-pit mine } & \\
\hline $\begin{array}{l}\text { Mecha- } \\
\text { nical } \\
\text { part }\end{array}$ & 17520 & 610 & 19,3 & 29,7 & $\begin{array}{l}\text { Expo- } \\
\text { nential }\end{array}$ \\
\hline $\begin{array}{l}\text { Electric } \\
\text { part }\end{array}$ & 17520 & 585 & 63,2 & 11,6 & $\begin{array}{l}\text { Expo- } \\
\text { nential }\end{array}$ \\
\hline \multirow[t]{2}{*}{$\begin{array}{l}\text { Control } \\
\text { system }\end{array}$} & 17520 & 67 & 10,4 & 72,1 & $\begin{array}{l}\text { Expo- } \\
\text { nential }\end{array}$ \\
\hline & \multicolumn{4}{|c|}{ Bachatsky open-pit mine } & \\
\hline $\begin{array}{l}\text { Mecha- } \\
\text { nical } \\
\text { part }\end{array}$ & 17520 & 523 & 18,7 & 27,4 & $\begin{array}{l}\text { Expo- } \\
\text { nential }\end{array}$ \\
\hline $\begin{array}{l}\text { Electric } \\
\text { part }\end{array}$ & 17520 & 585 & 53,2 & 10,6 & $\begin{array}{l}\text { Expo- } \\
\text { nential }\end{array}$ \\
\hline \multirow{2}{*}{$\begin{array}{l}\text { Control } \\
\text { system }\end{array}$} & 17520 & 69 & 11,4 & 73,1 & $\begin{array}{l}\text { Expo- } \\
\text { nential }\end{array}$ \\
\hline & \multicolumn{4}{|c|}{ Kaltansky open-pit mine } & \\
\hline $\begin{array}{l}\text { Mecha- } \\
\text { nical } \\
\text { part }\end{array}$ & 17520 & 823 & 27,2 & 43,5 & $\begin{array}{l}\text { Expo- } \\
\text { nential }\end{array}$ \\
\hline $\begin{array}{l}\text { Electric } \\
\text { part }\end{array}$ & 17520 & 745 & 81,2 & 19,8 & $\begin{array}{l}\text { Expo- } \\
\text { nential }\end{array}$ \\
\hline \multirow[t]{2}{*}{$\begin{array}{l}\text { Control } \\
\text { system }\end{array}$} & 17520 & 88 & 17,3 & 78,3 & $\begin{array}{l}\text { Expo- } \\
\text { nential }\end{array}$ \\
\hline & \multicolumn{4}{|c|}{ Taldinsky open-pit mine } & \\
\hline $\begin{array}{l}\text { Mecha- } \\
\text { nical } \\
\text { part }\end{array}$ & 17520 & 647 & 31,1 & 31,8 & $\begin{array}{l}\text { Expo- } \\
\text { nential }\end{array}$ \\
\hline $\begin{array}{l}\text { Electric } \\
\text { part }\end{array}$ & 17520 & 623 & 77,3 & 11,6 & $\begin{array}{l}\text { Expo- } \\
\text { nential }\end{array}$ \\
\hline $\begin{array}{l}\text { Control } \\
\text { system }\end{array}$ & 17520 & 68 & 10,3 & 79,5 & $\begin{array}{l}\text { Expo- } \\
\text { nential }\end{array}$ \\
\hline
\end{tabular}

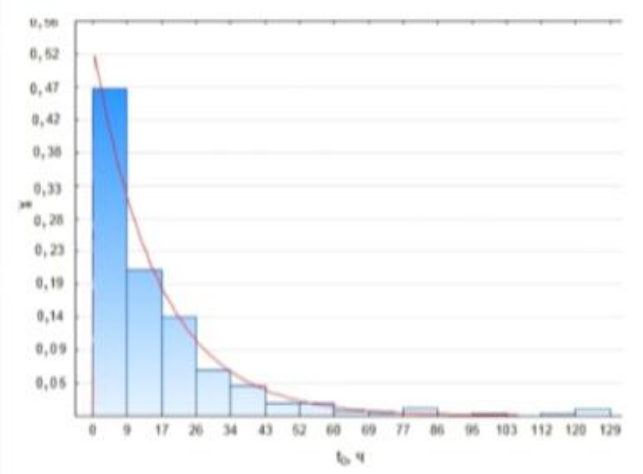

Figure 1. Histograms and distribution frequency functions of a time per fault of a mechanical part of rope shovels 


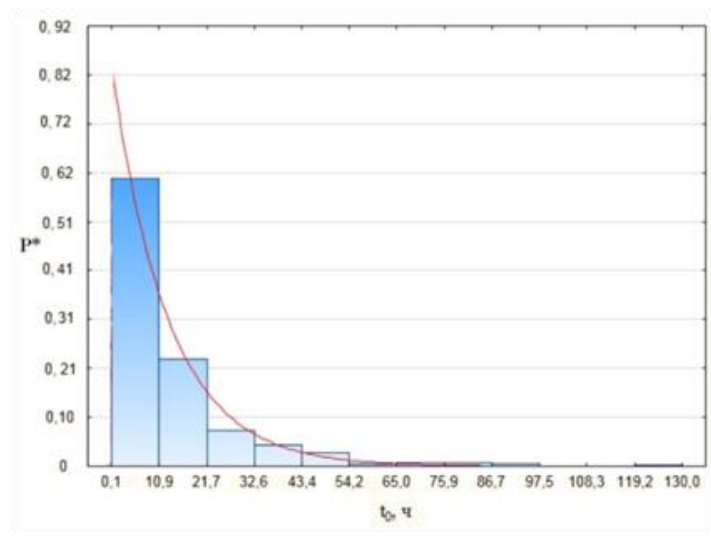

Figure 2. Histograms and distribution frequency functions of a time per fault of an electric part of rope shovels

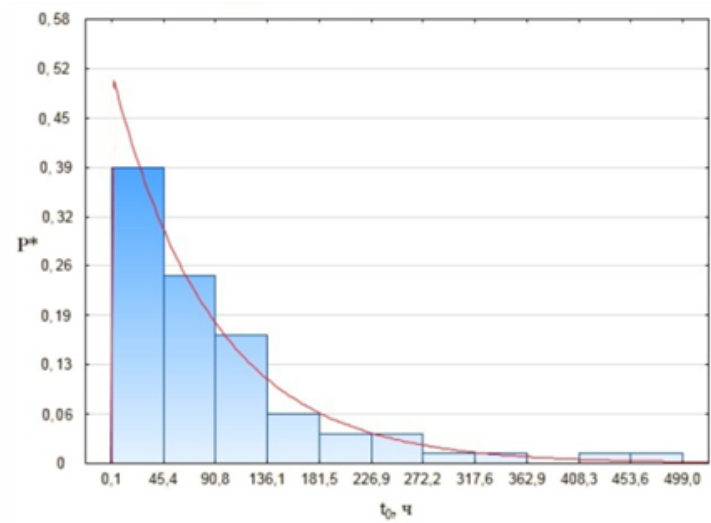

Figure 3. Histograms and distribution frequency functions of a time per fault of a control system of rope shovels

In fig. $1-3$ histograms and distribution frequency functions of time of rope shovel no-failure operation are shown on open-pit mine Kedrovsky.

Reconstructibility parameters of electromechanical system of rope shovels are presented in tab. 2 .

Table 2. The distribution law parameters of a time per fault of rope shovel electromechanical system

\begin{tabular}{|c|c|c|c|c|c|}
\hline $\begin{array}{l}\text { Ele- } \\
\text { ments } \\
\text { sys- } \\
\text { tems } \\
\end{array}$ & $\begin{array}{l}\text { Time of } \\
\text { obser- } \\
\text { vation } t, h\end{array}$ & $\begin{array}{l}\text { Quantity } \\
\text { of random } \\
\text { values in a } \\
\text { row }\end{array}$ & $\begin{array}{l}\text { Intensity } \\
\text { of } \\
\text { restitutio } \\
\mathrm{n}, 1 / \mathrm{h}\end{array}$ & $\begin{array}{l}\text { Mean time } \\
\text { to repair } \\
t_{\mathrm{R}}, \mathrm{h}\end{array}$ & $\begin{array}{l}\text { Distri- } \\
\text { bution } \\
\text { law }\end{array}$ \\
\hline \multicolumn{6}{|c|}{ Kedrovsky open-pit mine } \\
\hline $\begin{array}{l}\text { Mecha- } \\
\text { nical part }\end{array}$ & 17520 & 627 & 0,12 & 8,57 & $\begin{array}{l}\text { Expo- } \\
\text { nential }\end{array}$ \\
\hline $\begin{array}{l}\text { Electric } \\
\text { part }\end{array}$ & 17520 & 640 & 0,15 & 6,67 & $\begin{array}{l}\text { Expo- } \\
\text { nential }\end{array}$ \\
\hline $\begin{array}{l}\text { Control } \\
\text { system }\end{array}$ & 17520 & 77 & 0.26 & 3,86 & $\begin{array}{l}\text { Expo- } \\
\text { nential }\end{array}$ \\
\hline \multicolumn{6}{|c|}{ Krasnobrodsky open-pit mine } \\
\hline $\begin{array}{l}\text { Mecha- } \\
\text { nical }\end{array}$ & 17520 & 810 & 0,13 & 8,96 & $\begin{array}{l}\text { Expon } \\
\text { ential }\end{array}$ \\
\hline
\end{tabular}

\begin{tabular}{|c|c|c|c|c|c|}
\hline \multirow{3}{*}{$\begin{array}{l}\text { Electric } \\
\text { part } \\
\text { Control } \\
\text { system }\end{array}$} & 17520 & 793 & 0,16 & 7,01 & $\begin{array}{l}\text { Expo- } \\
\text { nential }\end{array}$ \\
\hline & 17520 & 91 & 0,28 & 3,99 & $\begin{array}{l}\text { Expo- } \\
\text { nential }\end{array}$ \\
\hline & \multicolumn{4}{|c|}{ Mokhovsky open-pit mine } & \\
\hline $\begin{array}{l}\text { Mecha- } \\
\text { nical } \\
\text { part }\end{array}$ & 17520 & 610 & 0,11 & 8,17 & $\begin{array}{l}\text { Expo- } \\
\text { nential }\end{array}$ \\
\hline $\begin{array}{l}\text { Electric } \\
\text { part }\end{array}$ & 17520 & 585 & 0,14 & 6,98 & $\begin{array}{l}\text { Expo- } \\
\text { nential }\end{array}$ \\
\hline $\begin{array}{l}\text { Control } \\
\text { system }\end{array}$ & 17520 & 67 & 0.25 & 3,78 & $\begin{array}{l}\text { Expo- } \\
\text { nential }\end{array}$ \\
\hline \multicolumn{6}{|c|}{ Bachatsky on open-pit mine } \\
\hline $\begin{array}{l}\text { Mecha- } \\
\text { nical } \\
\text { part }\end{array}$ & 17520 & 523 & 0,10 & 8,59 & $\begin{array}{l}\text { Expo- } \\
\text { nential }\end{array}$ \\
\hline $\begin{array}{l}\text { Electric } \\
\text { part }\end{array}$ & 17520 & 585 & 0,13 & 6,31 & $\begin{array}{l}\text { Expo- } \\
\text { nential }\end{array}$ \\
\hline $\begin{array}{l}\text { Control } \\
\text { system }\end{array}$ & 17520 & 69 & 0.21 & 3,81 & $\begin{array}{l}\text { Expo- } \\
\text { nential }\end{array}$ \\
\hline \multicolumn{6}{|c|}{ Kaltansky open-pit mines } \\
\hline $\begin{array}{l}\text { Mecha- } \\
\text { nical } \\
\text { part }\end{array}$ & 17520 & 823 & 0,14 & 9,06 & $\begin{array}{l}\text { Expo- } \\
\text { nential }\end{array}$ \\
\hline $\begin{array}{l}\text { Electric } \\
\text { part }\end{array}$ & 17520 & 745 & 0,17 & 7,21 & $\begin{array}{l}\text { Expo- } \\
\text { nential }\end{array}$ \\
\hline $\begin{array}{l}\text { Control } \\
\text { system }\end{array}$ & 17520 & 88 & 0,29 & 3,92 & $\begin{array}{l}\text { Expo- } \\
\text { nential }\end{array}$ \\
\hline \multicolumn{6}{|c|}{ Taldinsky open-pit mine } \\
\hline $\begin{array}{l}\text { Mecha- } \\
\text { nical } \\
\text { part }\end{array}$ & 17520 & 647 & 0,13 & 8,67 & $\begin{array}{l}\text { Expo- } \\
\text { nential }\end{array}$ \\
\hline $\begin{array}{l}\text { Electric } \\
\text { part }\end{array}$ & 17520 & 623 & 0,12 & 8,47 & $\begin{array}{l}\text { Expo- } \\
\text { nential }\end{array}$ \\
\hline $\begin{array}{l}\text { Control } \\
\text { system }\end{array}$ & 17520 & 68 & 0.21 & 3,80 & $\begin{array}{l}\text { Expo- } \\
\text { nential }\end{array}$ \\
\hline
\end{tabular}

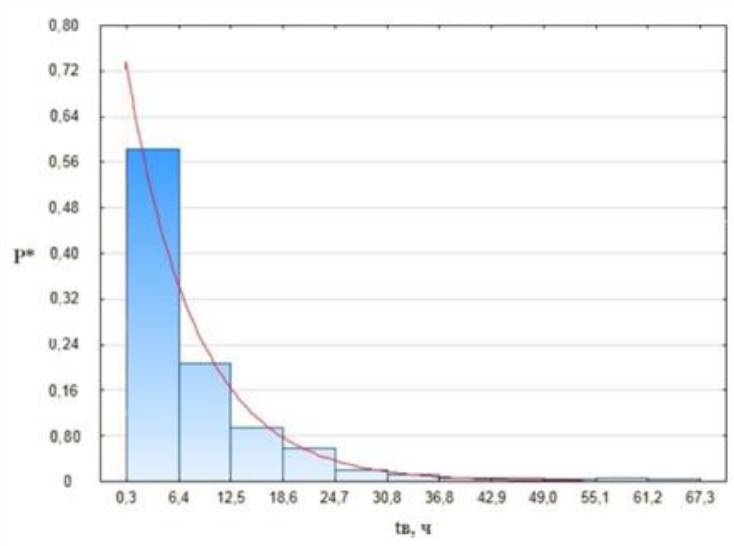

Figure 4. Histograms and distribution frequency functions of restoring time of a mechanical part of rope shovels 


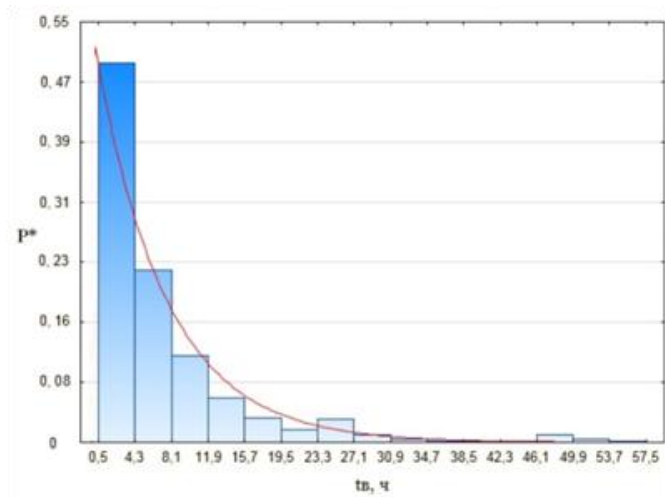

Figure 5. Histograms and distribution frequency functions of restoring time of an electric part of rope shovels

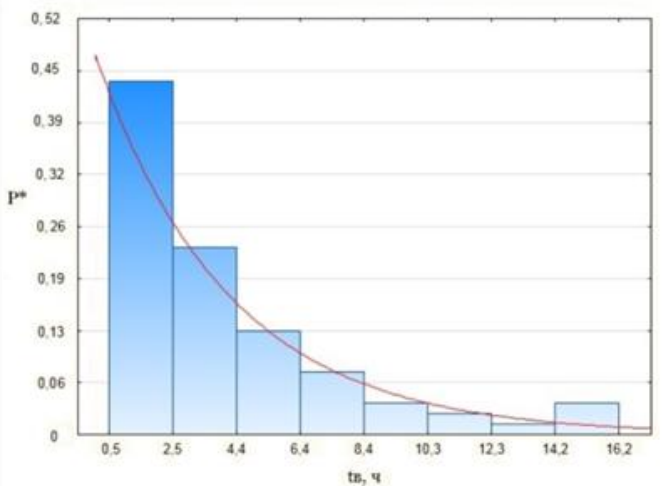

Figure 6. Histograms and distribution frequency functions of restoring time of management system of rope shovels

After processing of all statistical data from 6 open-pit mines it is possible to draw the following conclusions on time per fault and a restoring time::

1. The least time of no-failure operation of electromechanical system is the share of an electric part of rope shovels (the average time per fault $t_{0}$ makes $10,6 \mathrm{~h}$ (Bachatsky open-pit mine), and the greatest time of nofailure operation - on a control system of rope shovels $\left(t_{0}\right.$ $=91,2 \mathrm{~h}$ (Krasnobrodsky open-pit mine);

2. The greatest restoring time is the share of a mechanical part of rope shovels (mean restoring time $t_{\mathrm{R}}$ makes 9,06 h (Kaltansky open-pit mines), and the least restoring time - on a control system of rope shovels $\left(t_{\mathrm{R}}=\right.$ 3,78 (Mokhovsky open-pit mine);

3. Electric part of rope shovels has the largest failure rate $\lambda \cdot 10^{-3}=91,21 / \mathrm{h}$ (Krasnobrodsky open-pit mine).

Processing statistical data it is established that distributions of time per fault and a restoring time will most well be coordinated with the exponential law with a distribution frequency function of a type $f(t)=-$.
Table 3. Indexes of reliability of separate clusters and details of rope shovels of Kedrovsky open-pit mine for 2014 - 2015

\begin{tabular}{llllll}
\hline $\begin{array}{l}\text { List of } \\
\text { breakings }\end{array}$ & $\begin{array}{l}\text { Average } \\
\text { time } \\
\text { between } \\
\text { failures, } t_{0,}, \mathrm{~h}\end{array}$ & $\begin{array}{l}\text { Rate of } \\
\text { failure }\end{array}$ & $\begin{array}{l}\text { Total } \\
\text { number of }\end{array}$ & $\begin{array}{l}\text { Mean } \\
\text { time to } \\
\text { failures, h } \\
\text { repair } t_{\mathrm{B}},\end{array}$ & $\begin{array}{l}\text { Probability of } \\
\text { non-failure }\end{array}$ \\
$P(t)$
\end{tabular}




\section{Influence of operation activity level on reliability of an electromechanical inventory of rope shovels}

Reliability of electromechanical system of rope shovels is caused by smooth operation of its separate clusters which poor reliability reduces time of operation and efficiency of all complex of the rope shovel. The preliminary analysis of the emergency shutdowns of rope shovels on 6 open-pit mines showed that the largest duration of the outage times is the share of a mechanical part for the reasons of misuse of an inventory, low level of scheduled maintenance, influence of weather and climatic factors and also qualification of working personnel. For the detailed analysis of idle times the data on the most often found failures of rope shovels of the above-named openpit mines were processed.

Reliability indicators of separate clusters and details of the rope shovels affecting on their reliability are given in tab. 3. It is clear from the table that the greatest number of the emergency shutdowns - 197, happened because of rise engine failure. The considerable number of breakings was the result of caterpillar failure -173 , a ladle -165 , the course mechanism drive -157 and a rope -118 breakings. The highest failure rate $\lambda \cdot 10^{-3}$ falls on the rise engine - 18,541/h; caterpillars - $16,331 / \mathrm{h}$; a ladle $15,571 / \mathrm{h}$ and the course mechanism drive $-14,811 / \mathrm{h}$.. The greatest lost time $t_{\mathrm{B}}$ is the share of repair: a pressure reducer $-34,82 \mathrm{~h}$; a rise reducer $-28,97 \mathrm{~h}$; high-voltage cable crossing points $-20,43 \mathrm{~h}$ and a rope $-11,68 \mathrm{~h}$.

\section{Conclusions}

The received statistical data showed community of results on 6 open-pit mines located in various points of the Kuzbass coal basin.

That is why they can find application when scheduling maintenance and repairs and also other actions for increase in operational reliability of rope shovels on the open-pit mines.

\section{Acknowledgements.}

The authors express their gratitude to colleagues from the Power Institute of T.F. Gorbachev Kuzbass State Technical University for organizing and holding the conference "Energy and energy saving: theory and practice" in Dec. 2017 because the speech prepared for this conference formed the basis of this article.

\section{References}

[1] Dovzhenok A.C., Hajiev V.A. and Zakharov S.I. (2008) Dependence of the cost of maintenance and repair of mining equipment from the level of organizationaltechnological support. Equipment for mining, oil and gas industry: Collection of scientific works. Ekaterinburg, pp. 367-370.
[2] Zakharova A.G. and Shouleva N.M. (2008) Operational reliability of power supply systems of coal mines of Kuzbass. Mining journal, 11: $48-50$.

[3] Shadrin A.I. and .Ohron L (2013) Operational reliability of the excavators coal mine "Baganourski". Vestnik of Irkutsk state technical University, 8 (79): $37-40$.

[4] Golubev V.A. (2003) Reliability of electric equipment of excavators E1SG-8. Izv. Ural state mining University, 16: 33-35.

[5] Ivanov S.L. (2016) The Changing developments of the modern domestic excavators EKG from the conditions of their operation. Proceedings of the mining Institute, pp 692-700

[6] Golubev V.A., Bashmakov S.N., Komarov A.A. and N.I. Tarkhova (2003) New electric equipment for power supply of open cast mining, Izv.Ural state mining University.16: 62-67.

[7] RD 50-204-87. (1987) Reliability in technology. Collection and processing of information about the reliability of products in operation. Basic provisions. Publishing house of standards, pp 42.

[8] GOST 27.402-95 (2002). Reliability in technology. Test plans for monitoring the mean time between failure. Part 1 . Exponential distribution. Publishing house of standards, pp 41.

[9] Cox D. and Snell E. (1984) Applied statistics: Principles and examples. Mir, pp 200.

[10] Lvovskiy E.N. (1988) Statistical methods for constructing empirical formulas. SHK, pp 239.

[11] Siegel E (2004) Practical business statistics. Publishing house "Williams", pp 1056.

[12] Wentzel E.S. (1999) Probability theory/ Higher. SHK., pp 576.

[13] Bunn D. W. and Farmer E.D. (1985) Comparative models for electrical load forecasting. New York: Wiley, pp 232.

[14] Bunn D.W, and Larsen E.R. (1997) Systems Modelling for Energy Policy. - New York: Wiley. - 1997. - , pp 342.

[15] Taylor, J. (2008) An evaluation of methods for very shortterm loadforecasting using minute-by-minute British data // InternationalJournal of Forecasting, vol. 24, pp .645 658.

[16] Gould, H., Tobochnik J. and Christian W. (2006) An Introduction to Computer Simulation Methods. Applications to Physical System.: 3rd edition. AddisonWesley, pp 796.

[17] GOST R 27.003-2011 (2013) Reliability in engineering (SST). Reliability management. Guidance on specification of technical requirements for reliability. NATIONAL STANDARD OF THE RUSSIAN FEDERATION, pp 41.

[18] Becker R.G., Sobolev V.G. and Kuzmin G.S. (1975) Methods of collecting and processing statistical information about the reliability of mine electrical equipment. Steering technical material, pp 94. 